\title{
DETEKSI BAKTERI Escherichia coli DALAM AIR MINUM ISI ULANG YANG DISTERILISASI ULTRAVIOLET DI WILAYAH KECAMATAN JAGAKARSA
}

\section{MUZAJJANAH, YOSWITA RUSTAM, REZKI RACHMAWATI}

\begin{abstract}
Refill Water Depot is currently more widely circulated and used as an alternative drinking water supply by the public. However the still unclear about the quality of the drinking water refill generated primarily of biological content. Parameters of biological contamination in drinking water caused by the Escherichia coli and coliform bacterium. This study aims to identify E. coli and coliforms in drinking water refill. Refill drinking water samples obtained from 16 drinking water refill from Jagakarsa subdsitrict. The method used is descriptive. Refill drinking water samples was taken and tested in the MPN (Most Probable Number) method and then to be tested inidentification ofE. coli. The results of testing the drinking water refill obtained 15 samples positive for coliform bacteria. Samples were positive for E. coli bacteria that sample B.1 and F.2.
\end{abstract}

Keywords: Escherichia coli, coliform, MPN, identification test

\section{PENDAHULUAN}

Air merupakan sumber daya alam yang sangat penting dalam kehidupan baik tumbuhan, hewan maupun manusia. Air memiliki fungsi yang beragam seperti untuk memasak, mencuci, mandi dan sebagainya. Kehidupan manusia tidak terlepas dari kebutuhan akan air bersih terutama air minum. Sumber pemenuhan kebutuhan air minum berbagai macam diantaranya berasal dari air tanah, sungai, air pegunungan dan air laut. Air bersih secara umum yaitu air yang tidak berwarna, berbau dan tidak memiliki rasa.

Pemenuhan kebutuhan air minum yang bersih oleh masyarakat di kota besar semakin meningkat, sehingga produk air minum dalam kemasan banyak dikonsumsi. Akan tetapi air minum dalam kemasan cukup mahal, sehingga muncul produk yang dihasilkan oleh depot air minum isi ulang yang relatif terjangkau. Menurut Radji (2008), usaha depot air minum isi ulang berkembang pesat sejak tahun 2002 dengan harga yang relatif lebih murah jika dibandingkan dengan air minum dalam kemasan. Kualitas air minum isi ulang secara mikrobiologi masih diragukan karena dapat tercemar oleh bakteri E. coli maupun koliform. Berdasarkan Surat Keputusan Menteri Kesehatan No.907/Menkes/SK/VII/2002, bahwa salah satu

parameter mikrobiologi air minum yang wajib dipenuhi adalah batas minimum kandungan bakteri koliform dan E. coli sebanyak 0 per $100 \mathrm{ml}$. Menurut Madigan (2012), apabila bakteri E. coli ditemukan di dalam air, dapat menandakan adanya kontaminasi tinja dan air tersebut tidak aman untuk dikonsumsi. Menurut Collins (2004), bakteri E. coli juga berkaitan erat dengan infeksi 
beberapa penyakit pada manusia dan hewan.

Sterilisasi air minum isi ulang umumnya menggunakan ultraviolet. Ultraviolet mempunyai efek letal bagi sel mikroorganisme, sehingga digunakan oleh depot air minum isi ulang dalam proses sterilisasi. Menurut Saputra (2008), ultraviolet diketahui memiliki daya radiasi yang bersifat mematikan bagi mikroorganisme. Air minum isi ulang merupakan produk alternatif yang sudah banyak digunakan oleh masyarakat. Namun belum diketahui secara pasti apakah air minum isi ulang yang beredar telah terbebas dari bakteri E. coli dan koliform. Oleh karena itu, untuk mengetahui apakah di dalam air minum isi ulang yang disterilisasi ultraviolet terbebas dari bakteri E. coli, perlu adanya kajian mengenai deteksi bakteri E.coli dalam air minum isi ulang.

\section{METODE PENELITIAN}

Penelitian ini dilakukan di Laboratorium Mikrobiologi FMIPA UNJ pada bulan JanuariApril 2014. Metode penelitian yaitu deskriptif dengan cara observasi dan identifikasi bakteri E.coli. Sampel/depot air minum isi ulang diambil di kelurahan Jagakarsa, Srengseng Sawah, Tanjung Barat, Ciganjur, Cipedak, dan Lenteng Agung. Sampel/depot ditentukan dengan purposive sampling sebanyak 16 depot air minum isi ulang. Sampel diambil dengan menggunakan botol kaca steril sebanyak $250 \mathrm{ml}$ dari keran pengisian galon secara aseptis dan dimasukkan ke dalam ice box untuk diuji di laboratorium.

Sample diuji dengan metode MPN (Most Probable Number) menurut Wandrivel (2012) meliputi: uji pendugaan dengan media Lactose Broth, uji penegasan dengan media BGLBB, dan uji kesempurnaan dengan media Endo Agar. Uji pendugaan dilakukan dengan memasukkan sampel air minum isi ulang sebanyak $10 \mathrm{ml}$ ke dalam media Lactose Broth Double Strength ( $3 \mathrm{buah}$ ), $1 \mathrm{ml}$ ke dalam Lactose Broth Single Strength (3 buah), dan 0,1 ml Lactose Broth Single Strength (3 buah). Kemudia diinkubasi pada suhu suhu $37^{\circ} \mathrm{C}$ selama 24 - 48 jam. Hasil tabung yang positif ditandai oleh adanya gas dan perubahan warna media menjadi kuning. Kemudian dicatat dan dicocokkan dengan indeks tabel MPN menurut Collins (2004).

Hasil positif uji pendugaan dilanjutkan ke tahap uji penegasan dengan menginokulasikan 1-2 ose suspensi positif uji pendugaan ke dalam media BGLBB dan diinkubasi pada suhu suhu $44,5^{\circ} \mathrm{C}$ (koliform fekal) selama 24 - 48 jam. Hasil positif uji penegasan ditandai adanya gas pada tabung durham. Hasil positif uji penegasan dilanjutkan ke tahap uji kesempurnaan dengan memindahkan 1-2 ose suspensi hasil positif uji penegasan (bakteri fekal) ke media Endo Agar dengan cara goresan/ streak. Kemudian diinkubasi pada suhu $37^{\circ} \mathrm{C}$ selama $24-48$ jam. Hasil positif ditandai dengan adanya koloni yang berwarna hijau metalik dan warna merah. Hasil positif tersebut kemudian dibiakkan ke media Nutrient Agar sebagai isolat bakteri untuk uji identifikasi.

Deteksi/identifikasi bakteri E. coli melalui uji media selektif, pewarnaan Gram, uji fermentasi karbohidrat, uji IMViC (Indol, Methyl Red-Voges Proskauer, dan Citrate), uji TSIA (Triple Sugar Iron Agar), dan uji katalase. Hasil positif uji identifikasi E. coli meliputi: bakteri Gram negatif, positif methyl-red (ditandai oleh adanya warna merah setelah ditetesi indikator methyl red), negatif voges-proskauer (tidak adanya warna merah setelah ditetesi $\mathrm{KOH} 40 \%$ dan $\alpha$-naphtol), dan negatif sitrat (warna media tidak berubah). Ciri berikutnya yaitu bakteri E. coli mampu memfermentasi 
semua jenis karbohidrat (ditandai adanya gas dan perubahan warna media menjadi kuning karena adanya asam), memfermentasi glukosa, sukrosa/laktosa pada media TSIA sehingga bersifat asam pada bagian slant dan butt media, dan positif menghasilkan katalase dengan ditandai adanya gelembung setelah ditetesi larutan H202 $3 \%$ diatas suspensi bakteri pada object glass.

\section{HASIL DAN PEMBAHASAN}

Tabel 1. Hasil Indeks MPN dari uji pendugaan 16 sampel

\begin{tabular}{llll}
\hline Sumber sampel & Kombinasi tabung positif & Indeks MPN per $100 \mathrm{ml}$ & $\begin{array}{l}\text { Keteran- } \\
\text { gan }\end{array}$ \\
\hline Depot A.1 & $3-3-1$ & 4.6 & Lanjut \\
Depot A.2 & $3-3-0$ & 2.4 & Lanjut \\
Depot A.3 & $3-3-0$ & 2.4 & Lanjut \\
Depot A.4 & $3-2-1$ & 1.5 & Lanjut \\
Depot A.5 & $3-1-1$ & 0.75 & Lanjut \\
Depot B.1 & $3-2-1$ & 1.5 & Lanjut \\
Depot B.2 & $2-0-0$ & 0.092 & Lanjut \\
Depot C.1 & $3-1-1$ & 0.75 & Lanjut \\
Depot C.2 & $3-0-1$ & 0.38 & Lanjut \\
Depot D.1 & $0-0-0$ & - & - \\
Depot D.2 & $1-0-0$ & 0.036 & Lanjut \\
Depot E.1 & $3-3-1$ & 4.6 & Lanjut \\
Depot E.2 & $2-2-0$ & 0.21 & Lanjut \\
Depot F.1 & $2-0-0$ & 0.092 & Lanjut \\
Depot F.2 & $2-1-0$ & 0.15 & Lanjut \\
Depot F.3 & $1-2-0$ & 0.11 & Lanjut \\
\hline
\end{tabular}

Berdasarkan Tabel 1, sebanyak 15 sampel menunjukkan hasil positif koliform dan 1 sampel menunjukkan hasil negatif koliform. Hasil uji pendugaan yang positif koliform dilanjutkan ke tahap uji penegasan. Hasil uji penegasan disajikan pada Tabel 2.

Tabel 2. Hasil uji penegasan 15 sampel

\begin{tabular}{ccc}
\hline Sumber sampel & Hasil uji & Keterangan \\
\hline Depot A.1 & + & Lanjut \\
Depot A.2 & + & Lanjut \\
Depot A.3 & - & - \\
Depot A.4 & - & - \\
Depot A.5 & + & Lanjut \\
Depot B.1 & + & Lanjut \\
Depot B.2 & - & - \\
Depot C.1 & + & Lanjut \\
Depot C.2 & + & Lanjut \\
Depot D.2 & - & - \\
Depot E.1 & + & Lanjut \\
Depot E.2 & - & - \\
Depot F.1 & + & Lanjut \\
Depot F.2 & + & Lanjut \\
Depot F.3 & - & - \\
\hline
\end{tabular}


Tabel 3. Hasil uji kesempurnaan 9 sampel

\begin{tabular}{lll}
\hline No. & Sumber sampel & Warna koloni \\
\hline 1 & Depot A.1 & Pink \\
2 & Depot A.2 & Pink \\
3 & Depot A.5 & Pink \\
4 & Depot B.1 & Hijau metalik \\
5 & Depot C.1 & Merah \\
6 & Depot C.2 & Merah \\
7 & Depot E.1 & Pink \\
8 & Depot F.1 & Merah \\
9 & Depot F.2 & Hijau metalik \\
\hline
\end{tabular}

Sebanyak 9 sampel yang memberikan hasil uji positif pada uji penegasan, dan dilanjutkan ke tahap uji kesempurnaan. Hasil uji kesempurnaan dengan media selektif Endo Agar disajikan pada Tabel 3. Hasil positif uji kesempurnaan berdasarkan Tabel 3 yaitu sebanyak 5 sampel, terdiri dari : B.1, C.1, C.2, F.1, dan F.2. Koloni yang tumbuh dari kelima sampel tersebut selanjutnya ditumbuhkan kembali dengan Endo Agar. Hasil koloni yang tumbuh pada Endo Agar tersebut, kemudian diinokulasikan ke dalam media Nutrient Agar sebagai isolat bakteri untuk uji identifikasi. Hasil uji identifikasi 5 isolat bakteri disajikan pada Tabel 4.

Tabel 4. Hasil uji identifikasi 5 isolat bakteri

\begin{tabular}{lllllll}
\hline \multirow{2}{*}{ Uji Identifikasi } & Isolat & \multicolumn{5}{l}{ E. Coli } \\
\cline { 2 - 5 } & $\mathrm{B} .1$ & $\mathrm{C} .1$ & $\mathrm{C} .2$ & $\mathrm{~F} .1$ & $\mathrm{~F} .2$ & \\
\hline Uji Gram (-/+)* & - & - & - & - & - & - \\
Uji Gula-gula & & & & & & \\
(A/G)** & & & & & & \\
Glukosa & $\mathrm{A} / \mathrm{G}$ & $-/ \mathrm{G}$ & $-/ \mathrm{G}$ & $-/-$ & $\mathrm{A} / \mathrm{G}$ & $\mathrm{A} / \mathrm{G}$ \\
Laktosa & $\mathrm{A} / \mathrm{G}$ & $-/-$ & $-/ \mathrm{G}$ & $-/-$ & $\mathrm{A} / \mathrm{G}$ & $\mathrm{A} / \mathrm{G}$ \\
Dekstrosa & $\mathrm{A} / \mathrm{G}$ & $-/ \mathrm{G}$ & $-/ \mathrm{G}$ & $-/-$ & $\mathrm{A} / \mathrm{G}$ & $\mathrm{A} / \mathrm{G}$ \\
Mannitol & $\mathrm{A} / \mathrm{G}$ & $-/ \mathrm{G}$ & $-/-$ & $-/-$ & $\mathrm{A} / \mathrm{G}$ & $\mathrm{A} / \mathrm{G}$ \\
IMViC : & & & & & & \\
Indol & + & - & - & - & + & + \\
Methyl Red & + & - & - & - & + & + \\
Voges-Proskauer & - & - & - & - & - & - \\
Citrate & - & + & + & + & - & - \\
TSIA: (A/K)*** & & & & & & \\
Bagian Miring & $\mathrm{A}$ & $\mathrm{K}$ & $\mathrm{K}$ & $\mathrm{K}$ & $\mathrm{A}$ & $\mathrm{A}$ \\
Bagian Dasar & $\mathrm{A}$ & $\mathrm{K}$ & $\mathrm{K}$ & $\mathrm{K}$ & $\mathrm{A}$ & $\mathrm{A}$ \\
Gas & + & - & - & - & + & + \\
H2S & - & - & - & - & - & - \\
Katalase & + & + & + & + & + & + \\
\hline
\end{tabular}

Hasil uji MPN diperoleh 15 sampel tidak memenuhi syarat kualitas air minum secara mikrobiologi. Terdapat satu sampel (D.1) dengan hasil negatif koliform, sehingga dapat dinyatakan memenuhi syarat batas minimum koliform air minum isi ulang. Berdasarkan observasi dan wawancara, depot D.1 memiliki peralatan pengolahan air minum berupa filter tabung yang tidak rutin dilakukan penggantian. Hasil koliform tertinggi yaitu diperoleh dari sampel/depot A.1 dan 
E.1. observasi dan wawancara yang dilakukan depot A.1 dan E.1 bahwa depot memiliki filter tabung yang secara rutin diganti sekali setiap satu tahun dan filter mikro diganti sekali setiap dua bulan. Hasil ini menunjukkan bahwa penggantian peralatan depot tidak memiliki pengaruh pada besar/kecilnya jumlah total koliform di dalam air minum isi ulang.

E. coli memiliki sifat antara lain: termasuk bakteri gram negatif, bersifat motil, memfermentasi semua jenis gula, positif menghasilkan indol, positif uji methyl red, negatif uji voges-proskauer, dan negatif uji sitrat. E. coli dapat tumbuh pada media TSIA dengan memfermentasi glukosa dan sukrosa/laktosa. E. coli juga positif menghasilkan katalase (Odonkor, 2013). Seluruh kriteria tersebut dicocokkan dengan hasil uji yang telah didapatkan. Hasil uji didapatkan bahwa sampel yang positif terdeteksi mengandung bakteri E. coli yaitu sampel B.1 dan F.2.

Jumlah bakteri koliform dari isolat sampel air minum isi ulang tidak dipengaruhi pada kondisi peralatan depot. Menurut Asfawi (2004), kondisi peralatan yang digunakan depot air minum isi ulang dengan kualitas bakteriologis air minum tidak ada hubungan yang bermakna. Menurut kondisi peralatan yang digunakan depot air minum isi ulang dengan kualitas bakteriologis air minum tidak ada hubungan yang bermakna. Menurut Purwadi (2003) dalam Asfawi (2004), jumlah total koliform tidak mempunyai arti besar dalam penetapan kualitas air secara biologis, tetapi dapat memberikan gambaran tentang populasi bakteri di dalam air minum. Menurut Prescott (2002), kegiatan deteksi bakteri koliform dapat digunakan sebagai langkah utama dalam aspek mikrobiologi sanitasi.

Hasil pengamatan dan wawancara juga dilakukan pada depot yang terdeteksi bakteri E. coli yaitu depot B.1 dan F.2. Walaupun kedua depot air minum isi ulang tersebut telah melakukan proses sterilisasi dengan ultraviolet sebelum diisikan ke dalam galon. Hal ini dapat terjadi mungkin dikarenakan bakteri E. coli yang telah terdeteksi, mampu melakukan perbaikan kerusakan sel setelah disterilisasi ultraviolet, sehingga berpotensi dapat tumbuh kembali.

Menurut Zimmer (2002), dalam sistem distribusi air minum, air yang diolah dapat mengalami waktu penahanan yang panjang sebelum mencapai konsumen. Selama itu, mikroorganisme yang diiradiasi UV dapat memiliki kesempatan untuk melakukan perbaikan dan berpotensi tumbuh kembali dalam sistem. Dalam sistem pengolahan air minum, reaktivasi mikroba patogen terutama mikroorganisme indikator merupakan hal utama yang diperhatikan. Sehingga, jika mikroba indikator mampu aktif kembali, maka jumlah bakteri patogen dapat melebihi perkiraan.

\section{KESIMPULAN DAN SARAN}

Berdasarkan data hasil pengujian dapat disimpulkan bahwa, air minum isi ulang yang positif mengandung bakteri koliform yaitu sebanyak 15 sampel dan yang terdeteksi mengandung bakteri E. coli yaitu sebanyak 2 sampel yaitu B.1 dan F.2. Hasi penelitian ini dapat digunakan sebagai informasi untuk masyarakat atau dinas kesehatan setempat untuk melakukan kegiatan monitoring kualitas air minum isi ulang secara mikrobiologis di wilayah kecamatan Jagakarsa. Saran untuk penelitian ini adalah perlu dilakukan deteksi bakteri E. coli dalam air minum isi ulang dengan metode pengujian yang lebih efektif dan efisien. 


\section{DAFTAR PUSTAKA}

Asfawi, S. 2004. Analisis Faktor Yang Berhubungan Dengan Kualitas Bakteriologis Air Minum Isi Ulang Pada Tingkat Produsen Di Kota Semarang. Tesis. Dipublikasikan. eprints.undip.ac.id. 20 Juni 2014.

Collins, C.H., P.M. Lyne., J.M. Grange \& J. O Falkinham. 2004. Microbiological Methods. Arnold, London. Keputusan Menteri Kesehatan Republik Indonesia Nomor 907/Menkes/SK/VII/2002.http://betterwor k.org/ inlabourguide/wpcontent/uploads/Ke pmenkes_907. 17 Juni 2014.

Madigan, M., J. Martinko., D. Stahl \& D. Clark. 2012. Biology of Microorganisms. Pearson Education, United States of America.

Odonkor, S. T., Josep K. \& Ampofo. 2013. Escherichia coli as an indicator of bacteriological quality of water. Microbiology Research, Vol.4;e2.

Prescott, H. \& Klein's. 2002. Laboratory Exercise in Microbiology, Fifth Edition. The McGraw-Hill Companies.

Radji, M., Heria, O \& Herman, S. 2008. Pemeriksaan Bakteriologis Air Minum Isi Ulang Di Beberapa Depo Air Minum Isi Ulang Di Daerah Lenteng Agung Dan Srengseng Sawah Jakarta Selatan. ISSN : 1693-9883. Vol. V, No. 2, 101-109.

Saputra, A.I \& Imam, S. 2008. Penggunaan Alat Sterilisasi Air Minum Dengan Menggunakan Lampu Ultraviolet (UV) Dalam Skala Rumah Tangga. ISSN 1978- 6204. Ruwa Jurai - Vol. 2, No. 2.

Wandrivel, R., N. Suharti \& Y. Lestari. 2012. Kualitas Air Minum Yang Diproduksi Depot Air Minum Isi Ulang Di Kecamatan Bungus Padang Berdasarkan Persyaratan Mikrobiologi. Jurnal Kesehatan Andalas. 1(3). http:// jurnal.fk.unad.ac.id. 19 Juni 2013.

Zimmer, J. L \& R. M. Slawson. 2002. Potential Repair of Escherichia coli DNA following Exposure to UV Radiation from Both Medium-and Low-Pressure UV Sources Used in Drinking Water Treatment. Applied and Environmental Microbiology. 68 (7) : 3293. http://aem.asm.org. 15 September 2014. Pk. 00.56 WIB. 